\title{
In-Vitro dual inhibition of protein glycation, and oxidation by some Arabian plants
}

\author{
Maqsood A. Siddiqui ${ }^{1,3}$, Saima Rasheed ${ }^{2}$, Quaiser Saquib ${ }^{1,3}$, Abdulaziz A. Al-Khedhairy', Mansour S. Al-Said ${ }^{5}$, \\ Javed Musarrat ${ }^{4}$ and Muhammad lqbal Choudhary ${ }^{2 *}$
}

\begin{abstract}
Background: Diabetes mellitus is a metabolic disorder of epidemic proportion, projected to become the major cause of morbidity and mortality in the world in future. Despite extensive research in understanding this disease at molecular level, and the discovery of new drugs, diabetes and its complications remain largely untreated. Many of the late diabetic complications are associated with the glycation of proteins in the body. Natural flora has long been a rich source for therapeutic agents, especially against diabetes. The present study deals with the antiglycation properties of some medicinally important plants of Arabian region.
\end{abstract}

Methods: Twenty-six medicinal plants, commonly found in different regions of Arabian Peninsula, were evaluated for their protein anti-glycation activity by using BSA-MG glycation assay in-vitro. The extracts were incubated with BSA and MG at $37^{\circ} \mathrm{C}$ for 9 days, each sample was then examined for the presence of fluorescence ( $\lambda$ ex $330 \mathrm{~nm}$, and $\lambda e m 420 \mathrm{~nm}$ ), which represent the extent of protein glycation. Antioxidant activity was evaluated by using 1,1diphenyl- 2-picrylhydrazyl (DPPH), iron chelation, and superoxide radical scavenging asaays.

Results: The data revealed that out of 26 medicinal plants, five plants viz. Sida cordifolia, Plumbago zeylanica, Tribulus terrestris, Glycyrrhiza glabra, and Rosa indica were active against the in-vitro protein glycation with $I C_{50}$ values between $0.408-1.690 \mathrm{mg} / \mathrm{mL}$. Among the active plants, Glycyrrhiza glabra L. was found to be the most potent $\left(\mathrm{IC}_{50}=0.408 \pm 0\right.$. $027 \mathrm{mg} / \mathrm{mL})$, followed by Rosa indica $\left(I C_{50}=0.596 \pm 0.0179 \mathrm{mg} / \mathrm{mL}\right)$, and Sida cordifolia L. (IC $\left.50=0.63 \pm 0.009 \mathrm{mg} / \mathrm{mL}\right)$. The antioxidant potential of these plant extracts were also determined by using DPPH (2,2-diphenyl-1-picrylhydrazyl), iron chelation, and superoxide anion radical scavenging assays. Among five plants, Sida cordifolia exhibited a potent anti-oxidant activity in both DPPH and superoxide anion radical scavenging assays $\left(I C_{50}=0.005 \pm 0.0004\right.$, and $0.078 \pm 0$. $002 \mathrm{mg} / \mathrm{mL}$, respectively), followed by Rosa indica ( $\left(\mathrm{C}_{50}=0.023 \pm 0.0005\right.$ and $0.141 \pm 0.003 \mathrm{mg} / \mathrm{mL}$, respectively).

Conclusions: Protein glycation in hyperglycemic conditions involve oxidative changes. Therefore dual inhibition of protein glycation and oxidation are desirable properties in any test substance investigated for therapeutic purposes.

Keywords: Arabian medicinal plants, Diabetes, Advanced glycation end products (AGEs), Antioxidant, Glycyrrhiza glabra L., Rosa indica L., Sida cordifolia L.

\section{Background}

Diabetes mellitus (DM) is an impending public health challenge of the present century [1]. It affects over 387 million people globally, and this number is projected to increase to 592 million by 2035 . DM is currently the fourth leading cause of mortality in the world. It has also emerged as a major socioeconomic burden for

\footnotetext{
* Correspondence: iqbal.choudhary@iccs.edu; hej@cyber.net.pk

${ }^{2} H$.E.J. Research Institute of Chemistry, International Center for Chemical and

Biological Sciences, University of Karachi, Karachi 75270, Pakistan
}

Full list of author information is available at the end of the article developing countries [2]. In last three decades, extensive research has been conducted on glycation and anti-glycation processes in diabetes, based on the fact that the hyperglycemic condition or excess glucose in blood leads to the binding of free sugars with biomolecules [3-5]. Glycation is a spontaneous, nonenzymatic reaction between biomolecules (proteins, lipids, and DNA) and reducing sugars (such as glucose, fructose, and ribose), resulting in the formation of advanced glycation endproducts (AGEs) [6-8]. The accelerated process of proteins glycation has been identified as a 
marker, as well as a core reason for the onset of many diabetic complications, affecting the eyes, blood vessels, kidneys, skin, etc. $[9,10]$. Oxidative reactions are known to be involved in the protein glycation cascade. Most importantly, AGEs, via their receptors (RAGEs), inactivate the enzymes and promote the formation of reactive oxygen species (ROS). It is suggested that the generation of oxygen free radicals by glycation of biomolecules is one of the major biochemical pathways of oxidative tissue damage in diabetes. Search for agents with dual inhibitory effects, i.e. antioxidant and anti-glycation, is therefore a valid approach towards the treatment of complications resulting from non-enzymatic glycation reaction [11, 12]. Although extensive research has been conducted on various classes of glycation inhibitors, but none has reached to the clinical use. Therefore, there is an urgent need to identify the agents which inhibit or reverse the complex reactions of protein glycation, and oxidation.

Evidences about the anti-diabetic properties of medicinal plants have been continuously reported. During the last two decades, we have been focusing on bioactive natural products. This has led to the identification of several classes of safe and effective lead molecules [1216]. Information on dual inhibition pattern (anti-glycation and antioxidant activity) of traditional Arabian medicinal plants is scarce. So far no large-scale systematic study of the anti-glycation activity of medicinal herbs has been conducted. Therefore, the present study was designed to identify new and effective inhibitors of protein glycation during hyperglycemia from medicinal plants of Arabian region. We evaluated 26 medicinal plants, commonly found in different regions of Arabian Peninsula. These plants are used in herbal medicines for the treatment of different diseases, including diabetes.

\section{Methods}

\section{Chemicals}

Bovine serum albumin (BSA), and ethanol was purchased from Merck Marker Pvt. Ltd. (Germany), methylglyoxal (MG) (40\% aqueous solution), 2,2-diphenyl-1-picrylhydrazyl $(\mathrm{DPPH})$, iron chloride, ferrozine, $\beta$-nicotanamide adenine dinucleotide $(\mathrm{NADH})$, nitro blue tetrazolium (NBT), phenazine methosulphate (PMS), Quercetin (purity: $\geq 95.0 \%$ ), Gallic acid (purity: $\geq 98.0 \%$ ), and rutin (purity: $\geq 90 \%$ ) were from Sigma Aldrich (Japan). Sodium azide $\left(\mathrm{NaN}_{3}\right)$, disodium hydrogen phosphate $\left(\mathrm{Na}_{2} \mathrm{HPO}_{4}\right)$, and sodium dihydrogen phosphate $\left(\mathrm{NaH}_{2} \mathrm{PO}_{4}\right)$ were obtained from Scharlau Chemie, S. A. (Spain), while dimethyl sulphoxide (DMSO) was acquired from Fischer Scientific (UK).

\section{Plant material}

All plant samples were collected from different regions of Arabian Peninsula. Different parts of these plants (such as leaves, flowers, stems, or roots; Table 1) were separately processed for the preparation of crude extracts. Plants were identified by taxonomist at the Department of Botany, University of Karachi, Karachi, Pakistan (Herbarium voucher numbers are mentioned in supporting information). The samples were air-dried, protecting from sunlight, and powdered. These powdered samples were then stored at room temperature.

\section{Preparation of the crude extracts of medicinally important plants}

Crude extracts were prepared by extracting different powdered parts of the plants $(1 \mathrm{Kg})$ in $3 \mathrm{~L}$ distilled methanol. In brief, the extracts were obtained by triple soaking in methanol for 3 days (at room temperature) and the solvent was evaporated under reduced pressure. The crude extracts were then freeze dried, and the extracts were solublized in DMSO and used for the in-vitro experiments.

\section{In-vitro anti-glycation assay}

The reaction was performed in triplicate, and in such a way that in $200 \mu \mathrm{L}$ solution, the final concentration of BSA was $10 \mathrm{mg} / \mathrm{mL}$, methylglyoxal was $14 \mathrm{mM}$, and test extracts (dissolved in DMSO; final concentration $10 \%$ ) were $2 \mathrm{mg} / \mathrm{mL}$. Solution of methylglyoxal and BSA were prepared in phosphate buffer $(0.1 \mathrm{M}, \mathrm{pH} 7.4$, containing $3 \mathrm{mM}$ sodium azide as antimicrobial agent). Briefly, the $200 \mu \mathrm{L}$ of reaction mixture comprised of BSA $(50 \mu \mathrm{L})$, methylglyoxal $(50 \mu \mathrm{L})$, test extracts $(20 \mu \mathrm{L})$, and phosphate buffer $(80 \mu \mathrm{L})$, while in the negative control wells, $20 \mu \mathrm{L}$ of DMSO (final concentration $10 \%$ ) was added instead of test extracts. It was then incubated at $37{ }^{\circ} \mathrm{C}$ for 9 days (under sterile conditions). After incubation, each sample was examined for the development of fluorescence ( $\lambda$ ex $330 \mathrm{~nm}$ and $\lambda$ em $420 \mathrm{~nm}$ ), against blank on a microtitre plate reader (SpectraMax M5, Molecular Devices, CA, USA) [17]. Rutin was used as positive control. The percent inhibition of each extract was calculated by using the following formula:

\section{In-vitro antioxidant activities}

\section{DPPH Free radical scavenging assay}

Solution of DPPH $(0.3 \mathrm{mM})$ was prepared in ethanol, while different concentrations of the test extracts were prepared in DMSO. In each well of 96-wells plate, $5 \mu \mathrm{L}$ of the test extracts and $95 \mu \mathrm{L}$ of DPPH solution were added, and the pre-read (absorbance) was recorded at $515 \mathrm{~nm}$. The reaction was then incubated for $30 \mathrm{~min}$ at $37^{\circ} \mathrm{C}$. Plate was shaken for $1 \mathrm{~min}$ for thorough mixing and the change in absorbance was recorded at $515 \mathrm{~nm}$ 
on microplate-reader (SpectraMax M5, Molecular Devices, CA, USA) [18]. Gallic acid was used as a positive control. The percentage of DPPH radical scavenging was calculated by using following formula:

$$
\% \text { RSA }=100-(\Delta \mathrm{A} \text { Sample } / \Delta \mathrm{A} \text { Control }) \times 100
$$

(Where $\mathrm{RSA}=$ radical scavenging activity and $\Delta \mathrm{A}=$ change in absorbance)

\section{Iron chelation assay}

The $\mathrm{Fe}^{2+}$-chelating ability was determined according to the method of Koncic et al. with slight modifications [19]. In this assay, the concentration of $\mathrm{Fe}^{2+}$ ion was measured through the formation of ferrous ion-ferrozine complex. Plant extracts, dissolved in DMSO (2 mg/ $\mathrm{mL}, 5 \mu \mathrm{L})$, was mixed with $0.3 \mathrm{mM} \mathrm{FeCl}_{2}(35 \mu \mathrm{L})$ and $0.5 \mathrm{mM}$ ferrozine $(60 \mu \mathrm{L})$. Ferrozine reacted with the divalent iron resulting in the formation of stable violet colored complex (soluble in water). The mixture was shaken and left at room temperature for $10 \mathrm{~min}$. The change in the absorbance of the resulting mixture was measured at $562 \mathrm{~nm}$ by using SpectraMax M5 (Molecular Devices, CA, USA). Disodium EDTA was used as a reference compound.

\section{Superoxide anion radical scavenging assay}

The reaction mixture contained $10 \mu \mathrm{L}$ of crude plant extracts $(2 \mathrm{mg} / \mathrm{mL}$; dissolved in DMSO), $90 \mu \mathrm{L}$ of phosphate buffer (0.1 M; pH 7.4), $40 \mu \mathrm{L}$ of $(0.2 \mathrm{mM}) \beta$-nicotanamide adenine dinucleotide (NADH), and $40 \mu \mathrm{L}$ of $(0.081 \mathrm{mM})$ nitro blue tetrazolium (NBT). The reaction was initiated by the addition of $20 \mu \mathrm{L}$ of $(0.008 \mathrm{mM})$ phenazine methosulphate (PMS). The solutions of NADH, NBT and PMS were prepared in phosphate buffer (0.1 M; pH 7.4) [20]. The formation of superoxide was monitored by measuring the absorbance of the blue formazan dye after $5 \mathrm{~min}$ at $560 \mathrm{~nm}$ by using microtitre plate reader (SpectraMax M5, Molecular Devices, CA, USA). Quercetin was used as a positive control.

\section{Statistical analysis}

The results were analyzed by using SoftMax Pro Software (Molecular Devices, CA, USA), and expressed as the mean \pm S.E.M. of three experiments. The $\mathrm{IC}_{50}$ values were calculated by the EZ-Fit enzyme kinetics program (Perellela Scientific, Inc., Amherst, Mars, USA). GraphPad Prism 5, program was used for plotting dose dependant graphs of active plant extracts and for other graphs.

\section{Results}

Results revealed that out of 26 medicinal plants, five plants (i.e. Sida cordifolia, Plumbago zeylanica, Tribulus terrestris, Glycyrrhiza glabra, and Rosa indica) were able to inhibit the in-vitro protein glycation with $\mathrm{IC}_{50}$ values between $0.408-1.690 \mathrm{mg} / \mathrm{mL}$, while remaining plant extracts were found to be inactive as they showed less than $50 \%$ inhibition at $2 \mathrm{mg} / \mathrm{mL}$ concentration (Table 1). Among five active plants, Glycyrrhiza glabra L. was found to be the most potent $\left(\mathrm{IC}_{50}=0.408 \pm 0.027 \mathrm{mg} / \mathrm{mL}\right.$; Fig. 1$)$, followed by Rosa indica $\left(\mathrm{IC}_{50}=0.596 \pm 0.0179 \mathrm{mg} / \mathrm{mL}\right.$; Fig. 2) and Sida cordifolia L. $\left(\mathrm{IC}_{50}=0.63 \pm 0.009 \mathrm{mg} / \mathrm{mL}\right.$; Fig. 3). Extract of Plumbago zeylanica and Tribulus terrestris showed a week anti-glycation potential $\left(\mathrm{IC}_{50}=1.300 \pm\right.$ 0.033 and $1.690 \pm 0.020 \mathrm{mg} / \mathrm{mL}$, respectively), as compared to other active plants in this study (Table 1; Figs. 4 and 5).

The plants which were found to be active against protein glycation in-vitro (i.e. Sida cordifolia, Plumbago zeylanica, Tribulus terrestris, Glycyrrhiza glabra, and Rosa indica) were evaluated for DPPH radical scavenging activity. Figure 6 shows that all plants were active (Table 2; Fig. 6). Gallic acid was used as positive control in this assay. Results revealed that Sida cordifolia L. showed a potent antioxidant activity when compared with remaining four active plants.

In the next stage, five active plants (i.e. Sida cordifolia, Plumbago zeylanica, Tribulus terrestris, Glycyrrhiza glabra, and Rosa indica) were evaluated for iron chelating ability. Table 2 showed that none of these has the ability to chelate with the iron at $2 \mathrm{mg} / \mathrm{mL}$ concentration. In the final step of this study, selected plants were evaluated for superoxide anion radical scavenging activity. Results showed that, except G. glabra, all other plants were found to scavenge the superoxide anion radicals effectively (Table 2, Figs. 7, 8, 9 and 10).

\section{Discussion}

The present study was carried out to study medicinal plants of Arabian origin as anti-glycation agents. In this study, we systematically evaluated 26 medicinal plants for their anti-glycation activity potential (Table 1). Results revealed that out of 26 medicinal plants, five (i.e. Sida cordifolia, Plumbago zeylanica, Tribulus terrestris, Glycyrrhiza glabra, and Rosa indica) were found active against the in-vitro protein glycation. Among five active plants, Glycyrrhiza glabra L. (Voucher number: 37999) was found to be the most potent one. G. glabra belongs to the Fabaceae/Leguminosae family. It is famous for underground stems, which is widely used in flavor confectionery [21]. This plant is also known for its diverse biological activities, such as anti-inflammatory, antimicrobial, hepatoprotective properties. It is also used as 
Table 1 Anti-glycation activity of extracts of medicinally important plants of Arabian origin

\begin{tabular}{|c|c|c|c|c|c|c|}
\hline S. No. & Latin name & Family & Common English name & $\begin{array}{l}\text { Part of the } \\
\text { plant used }\end{array}$ & $\begin{array}{l}\text { \% Inhibition } \\
\text { (at } 2 \mathrm{mg} / \mathrm{mL} \text { ) }\end{array}$ & $\begin{array}{l}\mathrm{IC}_{50} \pm \mathrm{SEM} \\
(\mathrm{mg} / \mathrm{mL})^{1}\end{array}$ \\
\hline 1. & Abrus precatorius $\mathrm{L}$. & Fabaceae & Jequirity or Crab's eye & Fruits & 5.03 & $N A^{2}$ \\
\hline 2. & Acacia concinna (Willd.) DC. & Fabaceae & Soap-nut acacia & Fruits & -2.14 & $N A^{2}$ \\
\hline 3. & Azadirachta indica A. Juss. & Meliaceae & Indian-lilac & Fruits & 18.02 & $N A^{2}$ \\
\hline 4. & Balsamodendron mukul Hook. & Burseraceae & Indian bdellium & Gum & -8.24 & $N A^{2}$ \\
\hline 5. & $\begin{array}{l}\text { Calotropis procera } \\
\text { (Aiton) W. T. Aito. }\end{array}$ & Apocynaceae & Sodom apple & Flowers & 5.70 & $N A^{2}$ \\
\hline 6. & Cassia senna Linn. & Caesalpiniaceae & Senna & Leaves & 42.89 & $N A^{2}$ \\
\hline 7. & Chenopodium album L. & Amaranthaceae & Lamb's quarters & Whole plant & 9.68 & $N A^{2}$ \\
\hline 8. & Citrullus colocynthis (L.) Schrad. & Cucurbitaceae & Bitter apple & Fruits & -1.87 & $N A^{2}$ \\
\hline 9. & Daucus carota L. & Apiaceae & Wild carrot & Seeds & 13.26 & $N A^{2}$ \\
\hline 10. & Glycyrrhiza glabra L. & Fabaceae & Licorice/ Liquorice & Roots & 81.20 & $0.408 \pm 0.027$ \\
\hline 11. & Guilandina moringa $\mathrm{L}$. & Moringaceae & Moringa & Leaves & -29.72 & $N A^{2}$ \\
\hline 12. & Gymnema sylvestre R. Br. & Apocynaceae & Miracle fruit & Leaves & 39.28 & $N A^{2}$ \\
\hline 13. & Hedysarum alhagi L. & Fabaceae & Camelthorn & Fruit peel & 8.80 & $N A^{2}$ \\
\hline 14. & Lactuca sativa $\mathrm{L}$. & Asteraceae & Lettuce & Seeds & 34.51 & $N A^{2}$ \\
\hline 15. & Plumbago zeylanica $\mathrm{L}$. & Plumbaginaceae & Ceylon leadwort or Doctor bush & Branches & 64.53 & $1.300 \pm 0.033$ \\
\hline 16. & Punica granatum L. & Lythraceae & Pomegranate & Flowers & 0.293 & $N A^{2}$ \\
\hline 17. & Rhus coriaria L. & Anacardiaceae & Sumac & Seeds & 33.55 & $N A^{2}$ \\
\hline 18. & Rosa indica $\mathrm{L}$. & Rosaceae & Cyme rose & Flowers & 78.56 & $0.596 \pm 0.0179$ \\
\hline 19. & Sesamum indicum $\mathrm{L}$. & Pedaliaceae & Sesame & Seeds & -103.80 & $N A^{2}$ \\
\hline 20. & Sida cordifolia L. & Malvaceae & Country-mallow & Seeds & 81.98 & $0.63 \pm 0.009$ \\
\hline 21. & Tamarindus indica $\mathrm{L}$. & Fabaceae & Tamrhindi & Fruits & -3.85 & $N A^{2}$ \\
\hline 22. & Tephrosia purpurea (L.) Pers. & Fabaceae & Purple tephrosia & Branches & 33.26 & $N A^{2}$ \\
\hline 23. & Trianthema pentandra var. flava Blatt \& Halb. & Aizoaceae & Trianthema & Roots & 33.08 & $N A^{2}$ \\
\hline 24. & Tribulus terrestris $L$. & Zygophyllaceae & Devil's thorn & Seeds & 56.67 & $1.690 \pm 0.020$ \\
\hline 25. & Vitis vinifera $\mathrm{L}$. & Vitaceae & Wild grape & Fruits & 2.14 & $N A^{2}$ \\
\hline 26. & Zizyphus vulgaris Lam. & Rhamnaceae & Chinese date & Fruits & 0.286 & $N A^{2}$ \\
\hline 27. & Rutin $^{3}$ & - & - & - & 95.56 & 0.196 \\
\hline
\end{tabular}

${ }^{1} \mathrm{I} \mathrm{C}_{50}$ Values are presented in $\mathrm{mg} / \mathrm{mL} \pm$ standard error of mean of three assays; ${ }^{2} \mathrm{NA}$ : Not Active; ${ }^{3}$ Standard inhibitor for anti-glycation assay

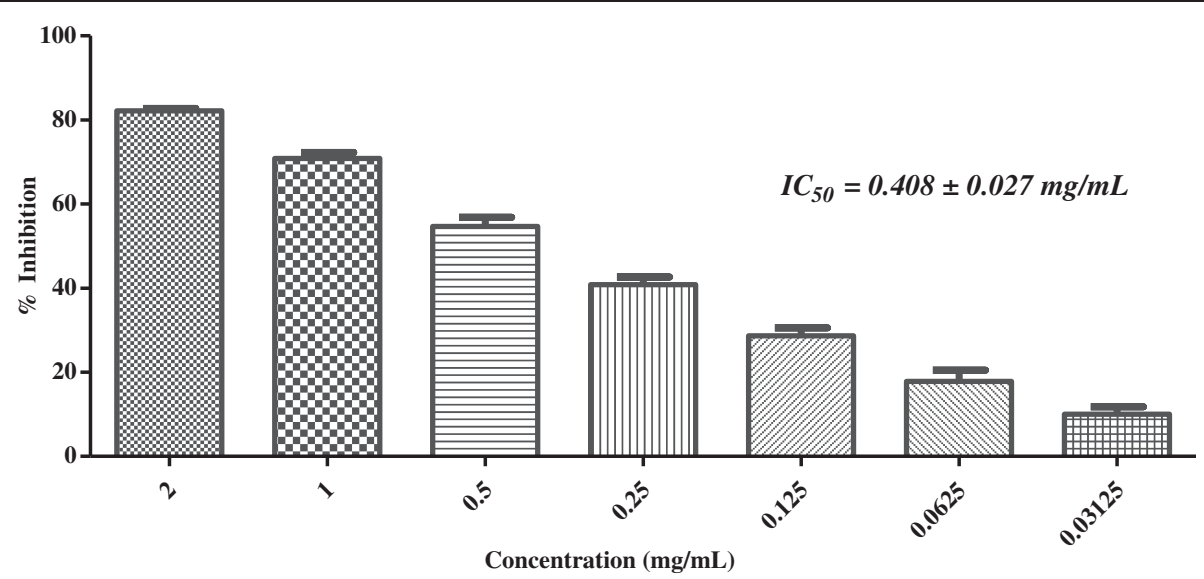

Fig. 1 In-vitro anti-glycation activity of methanolic extract of Glycyrrhiza glabra 


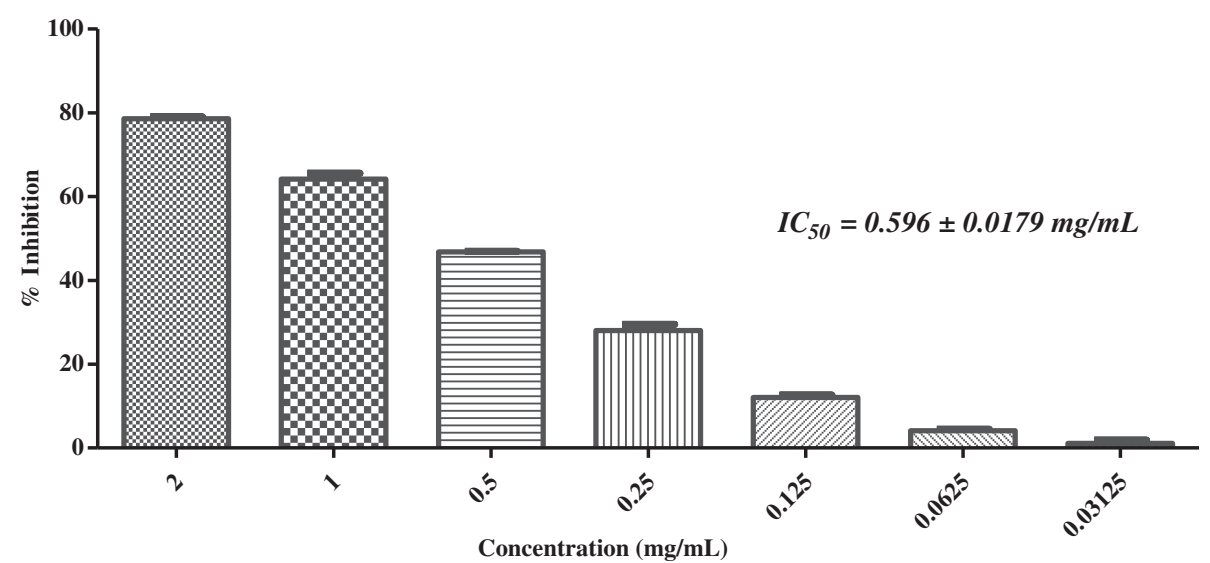

Fig. 2 In-vitro anti-glycation activity of methanolic extract of Rosa indica

folk remedy for sore throats, mouth ulcers, stomach ulcers, inflammatory stomach conditions, and indigestion [22-26]. G. glabra was also reported for hypoglycemic activity in rats [27]. G. glabra- based herbal formulations are known to exhibit anti-AGEs activities. Additionally a pure substance (glycyrrhizic acid) from the roots of this plant showed anti-glycation potential in high fat diet treated rats [14, 28, 29]. Major constituents of G. glabra include flavonoids, isoflavonoids, saponins, and tripentenes [30]. Literature has no report describing the invitro anti-glycation activity of root extracts of G. glabra. In our study methanolic extracts of G. glabra showed $63.42 \%$ inhibition $\left(\mathrm{IC}_{50}=0.408 \pm 0.027 \mathrm{mg} / \mathrm{mL}\right)$ in BSAMG glycation assay (Table 1; Fig. 1). Therefore in view of these results, G. glabra may be used as a therapeutic agent to reduce AGEs formation in diabetes.

Rosa indica L. (Voucher number: 91863) is an ornamental plant, known for perfuming effect. It possess pharmacological properties such as antioxidant, anti- fungal, anti-bacterial and urease inhibitory activities [31-33]. Manikandan et al. reported the synthesis of silver nanoparticles using extract of the petals of Rosa indica (ethanolic extract), and its in-vitro antibacterial, anticancer and anti-inflammatory activities. Different parts of $R$. indica (e.g. petals and buds) are known to treat runny nose, blocked bronchial tubes, asthma, and chest problems [34]. The bioactive compounds isolated, from Rosa indica, include flavonoids, alkaloids, phenols, saponins, and steroids [35]. There is no report describing the antiglycation activity of $R$. indica. In our in-vitro experimental assay, $R$. indica showed a good anti-glycation potential with $78.56 \%$ inhibition $\left(\mathrm{IC}_{50}=0.596 \pm 0.0179 \mathrm{mg} / \mathrm{mL}\right)$ (Table 1; Fig. 2).

The third most potent plant Sida cordifolia L. (Voucher number: 12135) belongs to Malvaceae family. Roots of S. cordifolia are used in coryza, pain, cardiac diseases, nervous disorders, and for anti-inflammatory, analgesic, hypoglycemic, antimicrobial, anti-hypercholesterolemic,

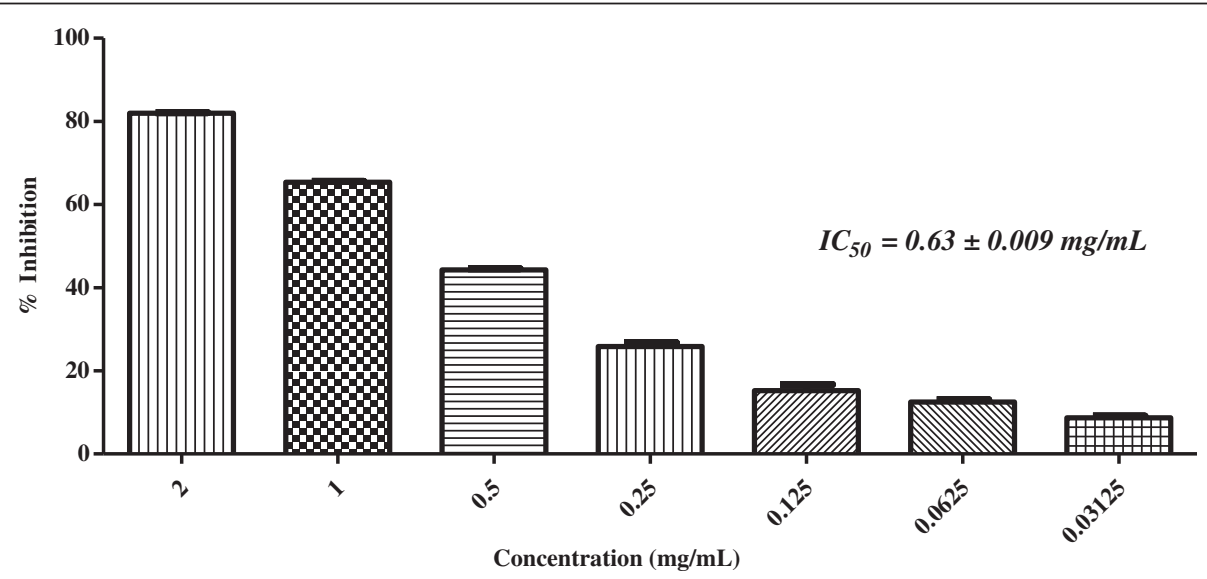

Fig. 3 In-vitro anti-glycation activity of methanolic extract of Sida cordifolia 


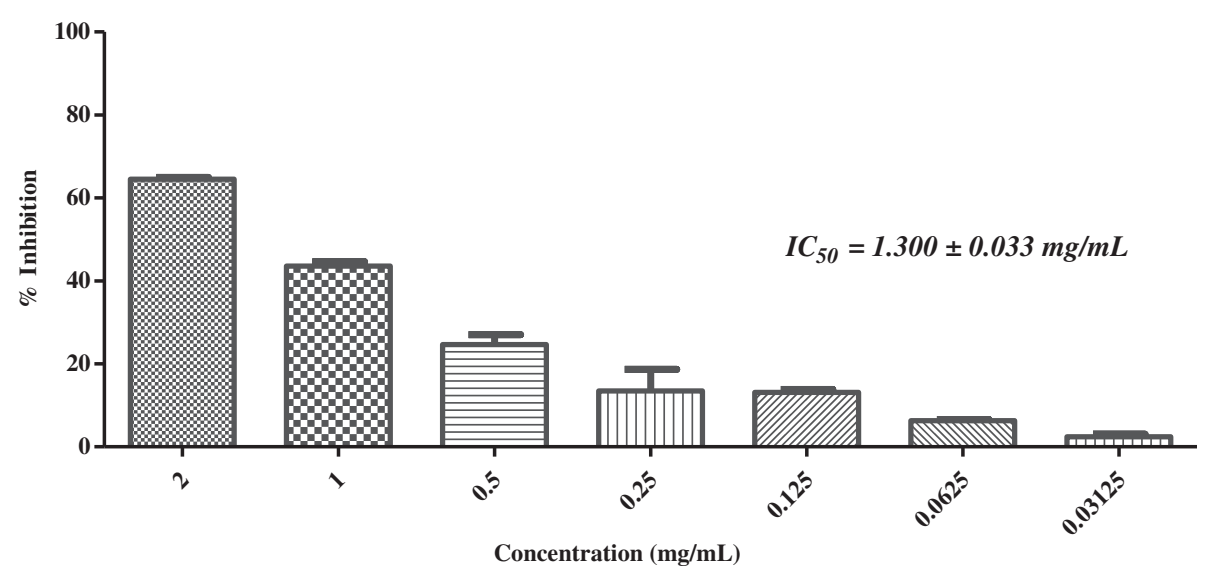

Fig. 4 In-vitro anti-glycation activity of methanolic extract of Plumbago zeylanica

antioxidant activities [36-40]. In addition, the extract of $S$. cordifolia has shown the anti-aging properties [41]. Major phytoconstituents of Sida cordifolia include alkaloids, flavonoids, steroids, phytoecdysteroids, and fatty acids [42]. As per literature survey, this is the first report describing the anti-glycation potential of the methanolic extracts of the seeds of $S$. cordifolia. In the present study, S. cordifolia showed $81.98 \%$ inhibition of BSA-MG glycation with $\mathrm{IC}_{50}=0.63 \pm 0.009 \mathrm{mg} / \mathrm{mL}$ (Table 1; Fig. 3).

Crude extract of Plumbago zeylanica L. (voucher No. 24177) and Tribulus terrestris L. (voucher No. 53177) showed a week anti-glycation potential $\left(\mathrm{IC}_{50}=1.300 \pm\right.$ 0.033 , and $1.690 \pm 0.020 \mathrm{mg} / \mathrm{mL}$, respectively), when compared with the other active plants of this study (Table 1; Fig. 4 and 5).

The plant $P$. zeylanica showed many biological properties, such as anti-inflammatory, hypolipidimic, wound healing, antidiabetic, memory-inducing, blood coagulation, anti-malarial, anti-fertility, anti-microbial, anticancer, antiviral, antioxidant, and anti-larvicidal activities. The phytochemical investigation showed that these biological activities are due to the presence of compounds, such as elliptinone, zeylanone, sistosterol and plumbagin [43]. Tribulus terrestris L. is known for several pharmacological properties, and its use in folk medicine for the treatment of impotence, edema, rheumatism, kidney stones, and hypertension. T. terrestris contains phenols, saponins, alkaloids and sterols as active constituents [44].

Oxidative reactions are known to be involved in the protein glycation cascade. Most importantly, AGEs via their receptors (RAGEs), inactivate the enzymes and promote the formation of reactive oxygen species. Dual activity, i.e. antioxidant and anti-glycation, is therefore a valid approach for the treatment of complications resulting from hyperglycemia $[11,12]$. The antioxidant activities of plants are mainly due to two mechanisms, i.e. scavenging the free radicals produced in the body or by chelating the transition metal [45]. Keeping this in view, all active plants (i.e. Sida cordifolia, Plumbago zeylanica, Tribulus terrestris, Glycyrrhiza glabra, and Rosa indica)

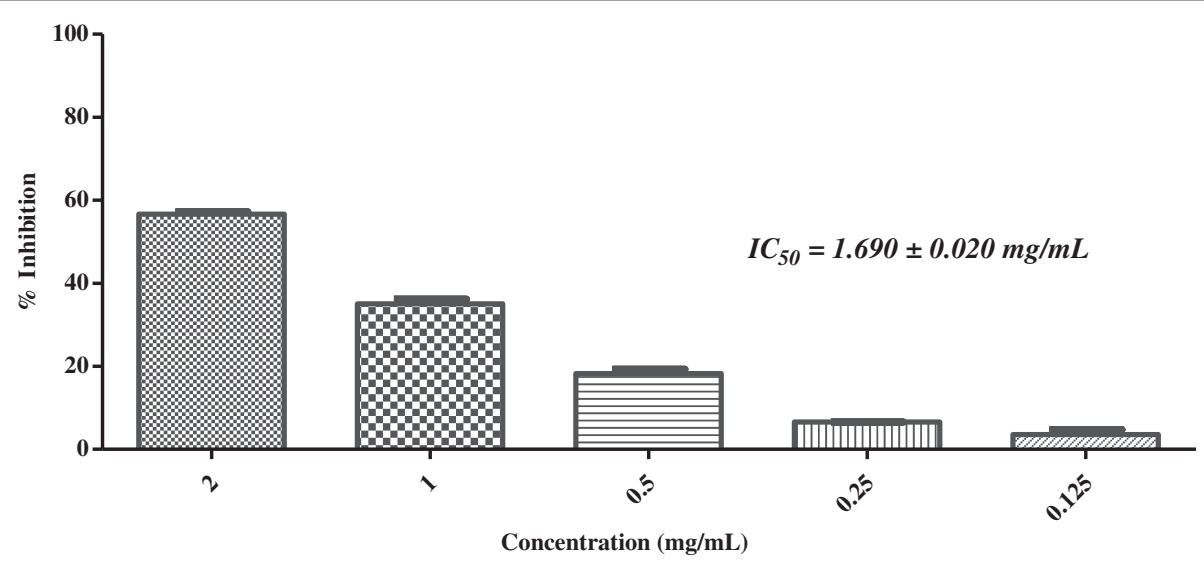

Fig. 5 In-vitro anti-glycation activity of methanolic extract of Tribulus terrestris 
Table 2 In-vitro antioxidant activity of medicinal plants of Arabian origin (which were found to be active in BSA-MG glycation assay)

\begin{tabular}{|c|c|c|c|c|c|}
\hline \multirow[t]{2}{*}{ Scientific Name } & \multicolumn{2}{|c|}{ DPPH radical scavenging activity } & \multirow{2}{*}{$\begin{array}{l}\text { Iron Chelation activity } \\
\% \text { Chelation }^{\mathrm{a}}\end{array}$} & \multicolumn{2}{|c|}{ Superoxide anion radical scavenging activity } \\
\hline & $\% \mathrm{RSA}^{\mathrm{a}}$ & $\mathrm{IC}_{50} \pm \mathrm{SEM}^{\mathrm{b}}(\mathrm{mg} / \mathrm{mL})$ & & $\%$ RSA & $\mathrm{IC}_{50} \pm \mathrm{SEM}^{\mathrm{b}}(\mathrm{mg} / \mathrm{mL})$ \\
\hline Glycyrrhiza glabra L. & 82.99 & $0.237 \pm 0.001$ & -9.50 & 5.00 & - \\
\hline Plumbago zeylanica L. & 74.94 & $0.044 \pm 0.001$ & -16.10 & 92.80 & $0.118 \pm 0.004$ \\
\hline Rosa indica L. & 74.15 & $0.023 \pm 0.0005$ & 1.90 & 97.20 & $0.141 \pm 0.003$ \\
\hline Sida cordifolia L. & 69.99 & $0.005 \pm 0.0004$ & 6.60 & 94.50 & $0.078 \pm 0.002$ \\
\hline Tribulus terrestris $\mathrm{L}$. & 79.69 & $0.157 \pm 0.002$ & 20.40 & 78.80 & $0.872 \pm 0.011$ \\
\hline Gallic acid ${ }^{b}$ & 93.13 & $0.004 \pm 0.0004$ & - & - & - \\
\hline EDTA $^{c}$ & - & - & 99.10 & - & - \\
\hline Quercetin $^{d}$ & - & - & - & 99.80 & $0.0318 \pm 0.001$ \\
\hline
\end{tabular}

${ }^{a}$ at $2 \mathrm{mg} / \mathrm{mL}$ concentration; $\mathrm{IC}_{50}$ Values are presented in $\mathrm{mg} / \mathrm{mL} \pm$ standard error of mean of three assays; ${ }^{\mathrm{b}, \mathrm{c}, \mathrm{d}}$ Standard inhibitors for antioxidant studies

were evaluated for their DPPH, superoxide anion radical scavenging and iron-chelating activities.

DPPH (2,2-diphenyl-1-picrylhydrazyl) is a stable free radical, in which electronic delocalization resulted in deep violet coloration. Certain plant extracts are able to donate hydrogen atoms and convert the DPPH radical into its reduced and stable form, and hence resulted in fading of violet color into pale yellow [45]. The in-vitro DPPH radical scavenging assay was performed with gallic acid as a positive control. Results revealed that all plants were active (Table 2; Fig. 6).

Glycation reaction, and AGEs are known to produce reactive oxygen intermediates (mainly superoxide anion and hydrogen peroxide) both in-vitro as well as in-vivo. In the in-vivo system, once generated, $\mathrm{H}_{2} \mathrm{O}_{2}$ can quickly enter inside the cell, while other activated oxygen species cannot. Within the cell, $\mathrm{H}_{2} \mathrm{O}_{2}$ can react with iron or copper in the Fenton reaction, and leads to the formation of hydroxyl radicals. These hydroxyl radicals contribute factors in diabetes-related oxidative stress [46]. Therefore metal chelators (e.g. Fe-chelators) can effectively serve as AGE-inhibitors. Interestingly when we evaluated the five active plants (i.e. S. cordifolia, P. zeylanica, T. terrestris, G. glabra, and $R$. indica) for iron chelating ability, all were found to be inactive, showing that they do not have ability to chelate with the iron at $2 \mathrm{mg} / \mathrm{mL}$ concentration.

Superoxide radical anion is formed from the reduction (i.e. one-electron) of free molecular oxygen by membranebound enzyme i.e. nicotinamide adenine dinucleotide phosphate Oxidase (NADPH). Ortwerth et al. reported that in glycation reaction, superoxide anion is formed by superoxide dismutase-dependent reduction of ferricytochrome C. They reported that Amadori products (formed from the reaction of lysine and small sugars) can generate superoxide anion even in the absence of metals [47]. Therefore, scavenging of superoxide anion was identifying as useful approach to inhibit the glycation mediated complications. In the final step of this study, we subjected all five plants for superoxide anion radical scavenging assay. Results showed that except G. glabra, all four plants scavenge the superoxide anion radicals effectively (Table 2, Figs. 7, 8, 9, and 10).

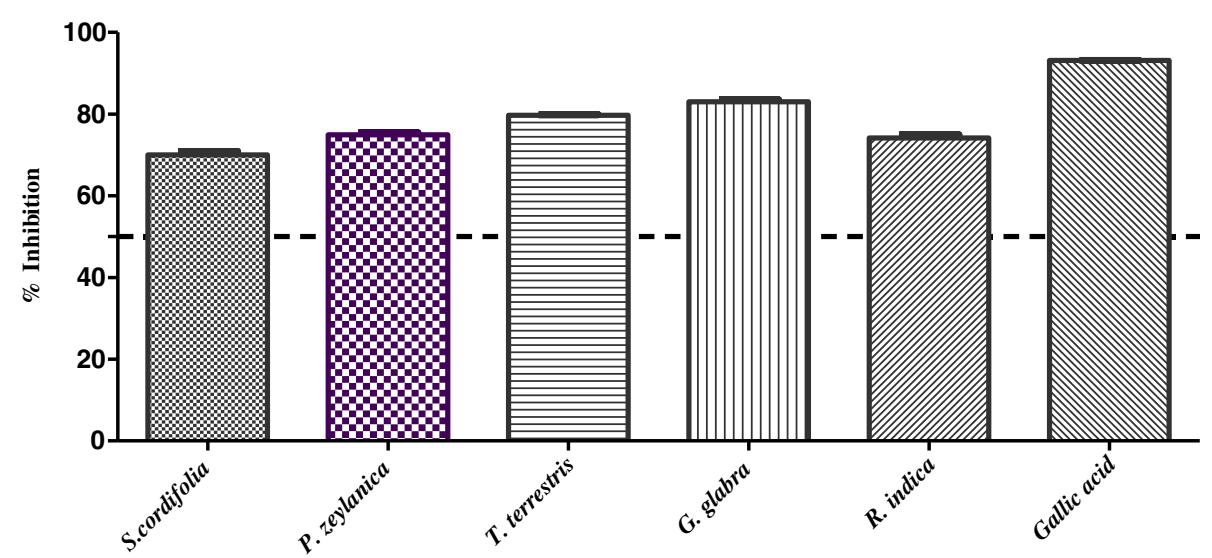

Fig. 6 In-vitro antioxidant (DPPH) activity of medicinally important plants of Arabian origin which were found to be active against in-vitro anti-glycation assay 


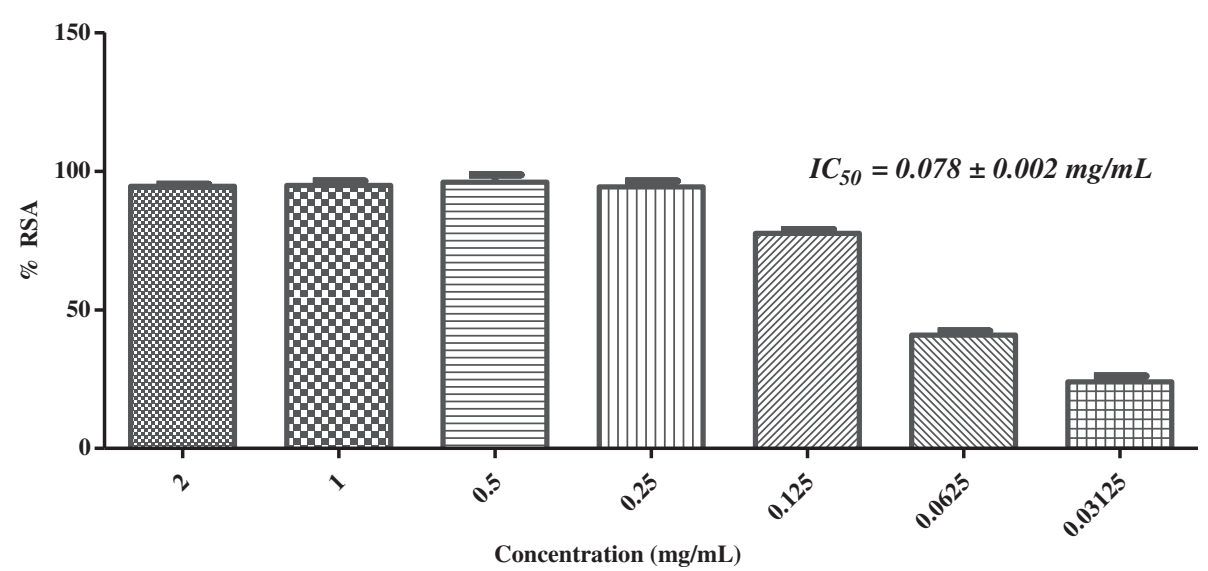

Fig. 7 In-vitro superoxide anion radical scavenging activity of methanolic extract of Sida cordifolia

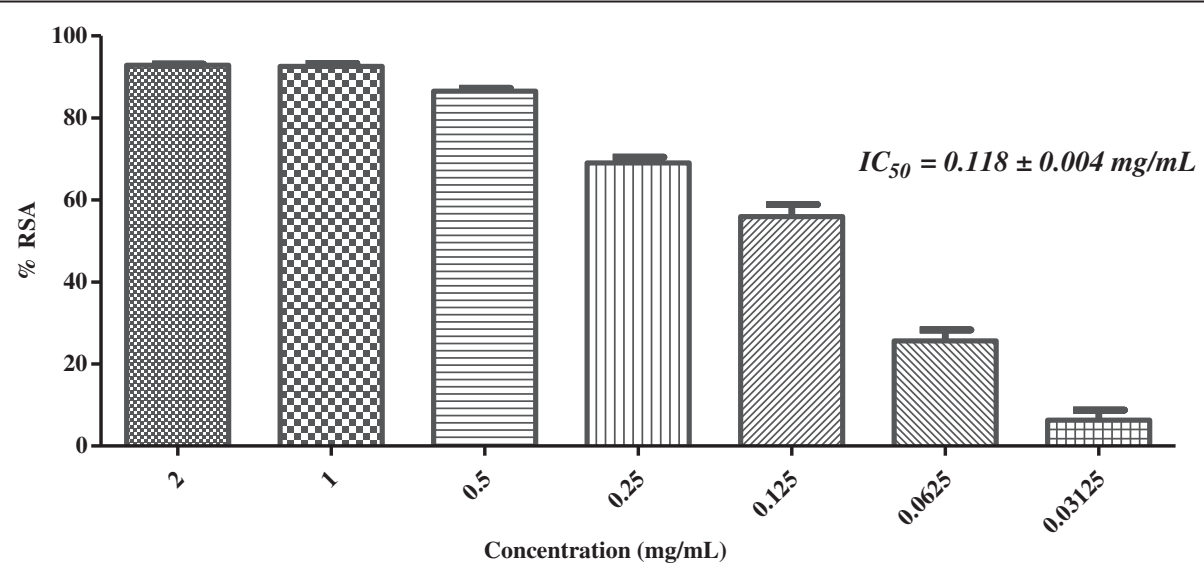

Fig. 8 In-vitro superoxide anion radical scavenging activity of methanolic extract of Plumbago zeylanica

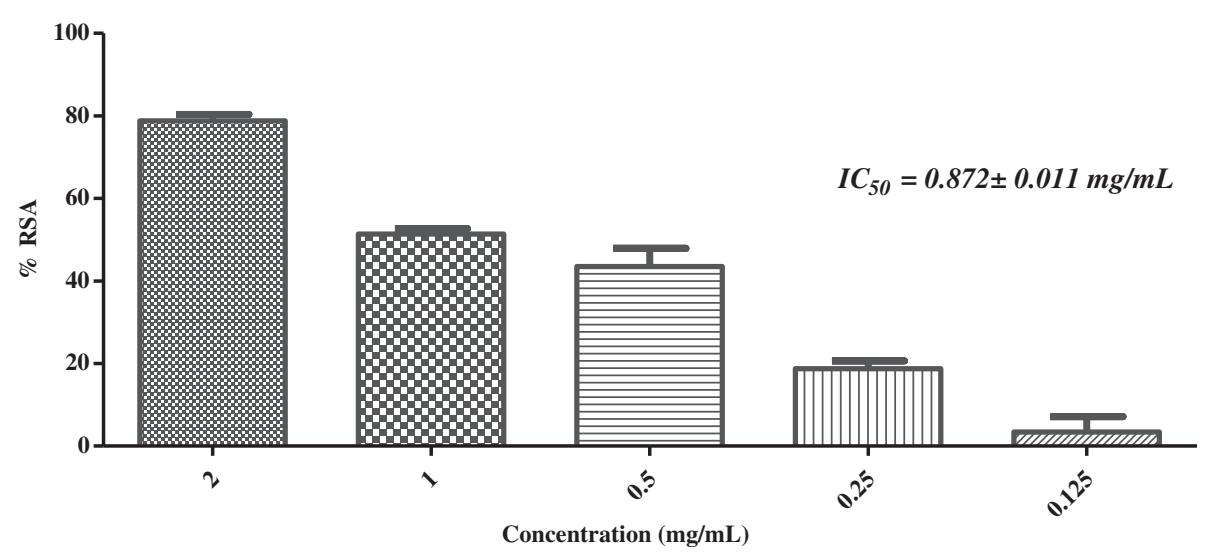

Fig. 9 In-vitro superoxide anion radical scavenging activity of methanolic extract of Tribulus terrestris 


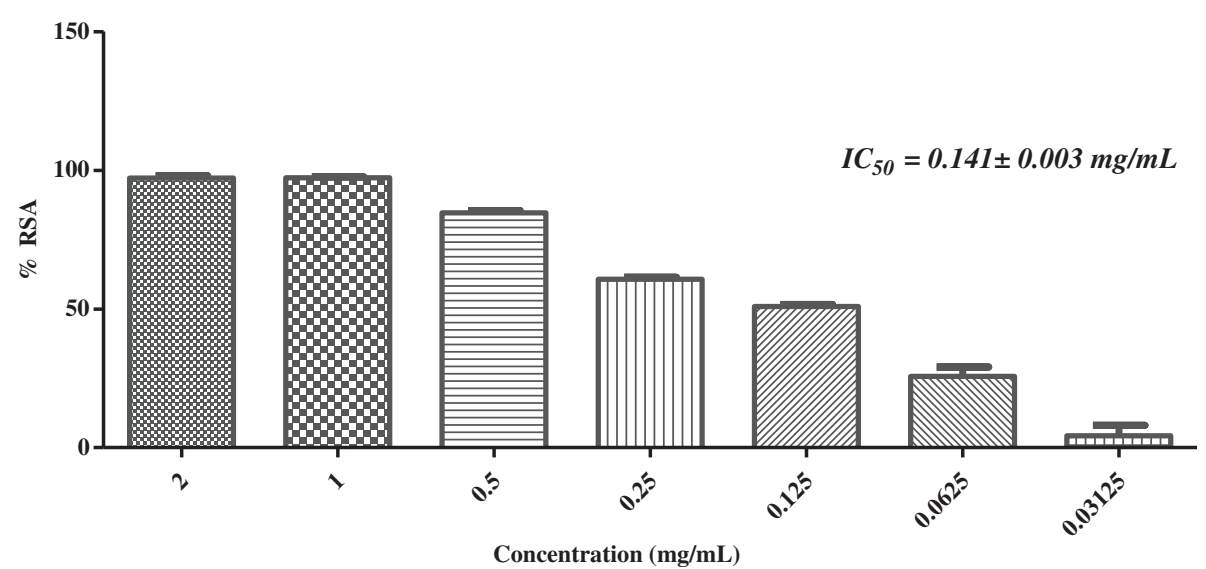

Fig. 10 In-vitro superoxide anion radical scavenging activity of methanolic extract of Rosa indica

\section{Conclusions}

In conclusion, the crude methanolic extracts of Rosa indica L., and Sida cordifolia L. have exhibited a potent protein anti-glycation activity in in-vitro BSA-MG antiglycation model. On the basis of these findings, one of the possible mechanisms of their reported antidiabetic activities is the inhibition of glycation and antioxidant properties. The anti-glycation activity of these medicinal plants are in good agreement with their uses in antidiabetic herbal medicines. Therefore, these plants needs to be further investigated phytochemically as well as pharmacologically to identify the active constituents and to establish their therapeutic potential against glycation induced pathologies in diabetes.

\section{Abbreviations}

AGEs, Advanced glycation endproducts; BSA, Bovine serum albumin; DM, Diabetes mellitus; DNA, Deoxyribonucleic acid; DPPH, 1,1-Diphenyl 2-picrylhydrazyl; em, Emission; ex, Excitation; $\mathrm{H}_{2} \mathrm{O}_{2}$ : Hydrogen peroxide; $\mathrm{IC}_{50}$ Half maximal inhibitory concentration; MG, Methylglyoxal; RAGEs: Receptor for advanced glycation endproducts; ROS, Reactive oxygen species

\section{Acknowledgements}

This project was funded by the National Plan for Science, Technology and Innovation (MAARIFAH), King Abdulaziz City for Science and Technology (KACST), Kingdom of Saudi Arabia (Award Number 12-MED2491-02).

\section{Availability of data and materials}

The datasets supporting this manuscript are included within the material and methods section of the article and also in the additional supporting information. These informations would be available for publication in the appropriate sections of this article.

\section{Authors' contributions}

MAS (Maqsood A. Siddiqui) designed the research proposal, and selected and arranged the plants for the study. SR (Saima Rasheed) was responsible for the in-vitro bioassays and interpretation of the bioassay results. QS (Quaiser Saquib) contributed the ethnobotanic data. AAA (Abdulaziz A. Al-Khedhairy) was involved in the proposal writing and finalization of manuscript. MSA (Mansour S. Al-Said) worked on research methodology and discussion on the results. JM (Javed Musarrat) worked on research methodology and antioxidant results. MIC (M. Iqbal Choudhary) has made substantial contribution for the interpretation of results and finalization of manuscript. All authors have read and approved the final manuscript.

\section{Competing interests}

The authors declare that they have no competing interests.

\section{Consent for publication}

As corresponding author, I give my permission for the material in this manuscript to appear in the print, and online version.

\section{Ethics approval and consent to participate}

This information is not relevant

\section{Author details}

'Department of Zoology, College of Science, King Saud University, P. O. Box. 2455, Riyadh 11451, Saudi Arabia. ${ }^{2}$ H.E.J. Research Institute of Chemistry, International Center for Chemical and Biological Sciences, University of Karachi, Karachi 75270, Pakistan. ${ }^{3}$ A. R. Al-Jeraisy Chair for DNA Research, Zoology Department, College of Science, King Saud University, P. O. Box. 2455, Riyadh 11451, Saudi Arabia. ${ }^{4}$ Department of Agriculture Microbiology, Faculty of Agriculture Sciences, AMU, Aligarh 202002, India. ${ }^{5}$ Departments of Pharmacognosy, College of Pharmacy, King Saud University, P. O. Box. 2455, Riyadh 11451, Saudi Arabia.

Received: 28 January 2016 Accepted: 15 July 2016

Published online: 05 August 2016

References

1. Zimmet $P$. The burden of type 2 diabetes: Are we doing enough? Diabetes Metab. 2003:29:659-18.

2. International Diabetes Federation (IDF). IDF Diabetes Atlas. 6th ed. Brussels: IDF; 2013

3. Finlayson C, Zimmerman D. Hyperglycemia not due to diabetes mellitus. Clin Pediatr Emerg Med. 2009;10:252-55.

4. Lorenzo C, Williams K, Hunt KJ, Haffner SM. The national cholesterol education program-Adult treatment panel III, international diabetes federation, and world health organization definitions of the metabolic syndrome as predictors of incident cardiovascular disease and diabetes. Diabetes Care. 2007;30:8-13.

5. Rondeau P, Bourdon E. The glycation of albumin: Structural and functional impacts. Biochimie. 2011;93:645-58.

6. Cho SJ, Roman G, Yeboah F, Konishi Y. The road to advanced glycation end products: A mechanistic perspective. Curr Med Chem. 2007;14:1653-71.

7. Li W, Zheng H, Bukuru J, De Kimpe N. Natural medicines used in the traditional Chinese medical system for therapy of diabetes mellitus. J Ethnopharmacol. 2004;92:1-21.

8. Ulrich P, Cerami A. Protein glycation, diabetes, and aging. Recent Prog Horm Res. 2001;56:1-21. 
9. Ahmed N. Advanced glycation end products- Role in pathology of diabetic complications. Diabetes Res Clin Pract. 2005;67:3-21.

10. Reddy VP, Beyaz A. Inhibitors of the Maillard reaction and AGE breakers as therapeutics for multiple diseases. Drug Discov Today. 2006;11:646-54.

11. Maritim AC, Sanders RA, Watkins JB. Diabetes, oxidative stress, and antioxidants: A review. J Biochem Mol Toxicol. 2003:17:24-38.

12. Yamaguchi F, Ariga T, Yoshimura Y, Nakazawa H. Antioxidative and antiglycation activity of garcinol from Garcinia indica fruit rind. J Agric Food Chem. 2000;48:180-85.

13. Ayatollahi SAM, Kobarfard F, Asgarpanah J, Choudhary MI. Anti-glycation activity of Otostegia persica (Burm.) Boiss. Afr J Biotechnol. 2010;9:3645-48.

14. Cheng HS, Kong JM, Ng AX, Chan WK, Ton SH, Kadir KA. Novel inhibitory effects of Glycyrrhizic Acid on the accumulation of advanced glycation end product and its receptor expression. Nat Prod Bioprospect. 2014;4:325-33.

15. Choudhary MI, Adhikari A, Rasheed S, Marasini BP, Hussain N, Kaleem WA, Atta-ur-Rahman. Cyclopeptide alkaloids of Ziziphus oxyphylla Edgw. as novel inhibitors of $a$-glucosidase enzyme and protein glycation. Phytochem Lett. 2011:4:404-06.

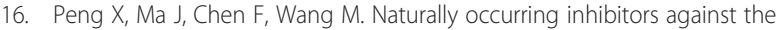
formation of advanced glycation end-products. Food Funct. 2011;2:289-301.

17. Zeb A, Malik I, Rasheed S, Choudhary MI, Basha FZ. Metronidazole esters: A new class of anti-glycation agents. Med Chem. 2012;8:846-52.

18. Orhan I, Kartal M, Naz Q, Ejaz A, Yilmaz G, Kan Y, Konuklugil B, Sener B, Choudhary MI. Antioxidant and anticholinesterase evaluation of selected Turkish Salvia species. Food Chem. 2007:103:1247-54.

19. Koncic MZ, Barbaric M, Perkovic I, Zorc B. Antiradical, chelating and antioxidant activities of hydroxamic acids and hydroxyureas. Molecules. 2011;16:6232-42.

20. Hazra B, Biswas S, Mandal N. Antioxidant and Free Radical Scavenging Activity of Spondias Pinnata. B.M.C. Complement Altern Med. 2008:8:63-73.

21. Vispute S, Khopade S. Glycyrrhiza Glabra Linn. "Klitaka": A review. Int J Pharm Biol Sci. 2011;2:42-5.

22. Dhingra D, Parle M, Kulkarni SK. Memory enhancing activity of Glycyrrhiza glabra in mice. J Ethnopharmacol. 2004;91:361-65.

23. Gupta VK, Fatima A, Faridi U, Negi AS, Shanker K, Kumar JK, Rahuja N, Luqman S, Sisodia BS, Saikia D, Darokar MP, Khanuja SPS. Antimicrobia potential of Glycyrrhiza glabra roots. J Ethnopharmacol. 2008;116:377-80

24. RenJie L. Optimization of extraction process of Glycyrrhiza glabra polysaccharides by response surface methodology. Carbohydr Polym. 2008; 74:858-61.

25. Sedighinia F, Afshar AS, Soleimanpour S, Zarif R, Asili J, Ghazvini K. Antibacterial activity of Glycyrrhiza glabra against oral pathogens: An in vitro study. Avicenna J Phytomed. 2012;2:118-24.

26. Wittschier N, Faller G, Hensel A. Aqueous extracts and polysaccharides from Liquorice roots (Glycyrrhiza glabra L.) inhibit adhesion of Helicobacter pylori to human gastric mucosa. J Ethnopharmacol. 2009;125:218-23.

27. Sitohy MZ, Massry RA, Saadany SS, Labib SM. Metabolic effects of licorice roots (Glycyrrhiza glabra) on lipid distribution pattern, liver and renal functions of albino rats. Nahrung. 1991;35:799-806.

28. Deetae P, Parichanon P, Trakunleewatthana P, Chanseetis C, Lertsiri S. Antioxidant and anti-glycation properties of Thai herbal teas in comparison with conventional teas. Food Chem. 2012;133:953-59.

29. Lo HY, Hsiang CY, Li TC, Li CC, Huang HC, Ho TY, Chen JC. A novel glycated hemoglobin A1c-lowering traditional Chinese medicinal formula, identified by translational medicine study. Plos One. 2014;9:e104650.

30. Parvaiz M, Hussain K, Khalid S, Hussnain N, Iram N, Hussain Z, Ali MA. A review: Medicinal importance of Glycyrrhiza glabra L. (Fabaceae family). Global J Pharmacol. 2014;8:8-13.

31. Bai S, Bharti P, Seasotiya L, Malik A, Dalal S. In vitro screening and evaluation of some Indian medicinal plants for their potential to inhibit Jack bean and bacterial ureases causing urinary infections. Pharm Biol. 2014:53:326-33.

32. Khan JA, Tewari S. A study on antibacterial properties of Rosa indica against various pathogens. Electron J Environ Agric Food Chem. 2011;10:2838-46.

33. Saeed R, Hameed-Ur-Rehman, Ali S, Ullah H, Ullah M, Rohullah, Hassan S, Farhan, Ahmed S, Akhwan S. Phytochemical analysis and anti-microbial activities of Rosa indica collected from Kohat Pakistan. Am J Phytomed Clin Ther. 2014;2:1370-77.

34. Manikandan R, Manikandan B, Raman T, Arunagirinathan K, Prabhu NM, Jothi BM, Perumal M, Palanisamy S, Munusamy A. Biosynthesis of silver nanoparticles using ethanolic petals extract of Rosa indica and characterization of its antibacterial, anticancer and anti-inflammatory activities. Spectrochim Acta A Mol Biomol Spectrosc. 2015;138:120-29.

35. Sahoo AM, Chakraborti CK, Nayak S, Kayal S. Correlation between phytochemical screening and in vitro antibacterial activity study of Rosa indica Linn. leaves. Int J Res Ayurveda Pharm. 2011;2:1595-97.

36. Derbre S, Morel S, Richomme P, Toure AK. Anti-glycation agent comprising a Garcinia kola extract or fraction. 2014.US Patent 20140142171 A1.

37. Franzotti EM, Santos CV, Rodrigues HM, Mourao RH, Andrade MR, Antoniolli AR. Anti-inflammatory, analgesic activity and acute toxicity of Sida cordifolia L. (Malva-branca). J Ethnopharmacol. 2000;72:273-77.

38. Kanth VR, Diwan PV. Analgesic, antiinflammatory and hypoglycaemic activities of Sida cordifolia. Phytother Res. 1999;3:75-7.

39. Mahesh B, Satish S. Antimicrobial activity of some important medicinal plant against plant and human pathogens. World J Agri Sci. 2008;4:839-43.

40. Momin MA, Bellah SF, Rahman SM, Rahman AA, Murshid GM, Emran TB. Phytopharmacological evaluation of ethanol extract of Sida cordifolia L. roots. Asian Pac J Trop Biomed. 2014;4:18-24.

41. Dhalwal K, Deshpande YS, Purohit AP, Kadam SS. Evaluation of the Antioxidant Activity of Sida cordifolia. Pharm Biol. 2005;43:754-61.

42. Galal A, Raman V, Khan IA. Sida cordifolia, a traditional herb in modern perspective-A review. Curr Tradit Med. 2015;1:5-17.

43. Jain P, Sharma HP, Basri F, Baraik B, Kumari S, Pathak C. Pharmacological Profiles of Ethno-Medicinal Plant: Plumbago zeylanica L. - A Review. Int Pharm Sci Rev Res. 2014;24:157-63.

44. Hammoda HM, Ghazy NM, Harraz FM, Radwan MM, ElSohly MA, Abdallah II. Chemical constituents from Tribulus terrestris and screening of their antioxidant activity. Phytochemistry. 2013;92:153-59.

45. Kazeem MI, Ashafa AOT. In-vitro antioxidant and antidiabetic potentials of Dianthus basuticus Burtt Davy whole plant extract. J Herb Med. 2015;5:158-64.

46. Khechai F, Ollivier V, Bridey F, Amar M, Hakim J, Prost D. Effect of advanced glycation end product-modified albumin on tissue factor expression by monocytes. Arterioscler Thromb Vasc Biol. 1997;17:2885-90.

47. Ortwerth BJ, James $H$, Simpson G, Linetsky M. The generation of superoxide anions in glycation reactions with sugars, osones, and 3-deoxyosones. Biochem Biophys Res Commun. 1998;245:161-5.

\section{Submit your next manuscript to BioMed Central and we will help you at every step:}

- We accept pre-submission inquiries

- Our selector tool helps you to find the most relevant journal

- We provide round the clock customer support

- Convenient online submission

- Thorough peer review

- Inclusion in PubMed and all major indexing services

- Maximum visibility for your research

Submit your manuscript at www.biomedcentral.com/submit 